\title{
Reply to comment on the article "Propagation of a lithospheric tear fault (STEP) through the western boundary of the Calabrian accretionary wedge offshore eastern Sicily (Southern Italy)" by Gallais et al., 2013 Tectonophysics
}

\author{
Flora Gallais ${ }^{\mathrm{a}}$, David Graindorge ${ }^{\mathrm{b}, \mathrm{c}}$, Marc-André Gutscher ${ }^{\mathrm{b}, \mathrm{c}, \text { * }}$
}

\author{
a Ifremer Centre de Brest, Laboratoire Géodynamique et Géophysique, Géosciences Marines, B.P. 70, 29280 \\ Plouzané Cedex, France \\ b Université Européenne de Bretagne, France \\ c Université de Brest, CNRS, UMR 6538 Domaines Océaniques, Institut Universitaire Européen de la Mer, Place \\ Nicolas Copernic, 29280 Plouzané, France
}

\author{
*: Corresponding author: Marc-André Gutscher, tel.: + 33298498727 ; fax: + 33298498760 ; \\ email address : gutscher@univ-brest.fr \\ graindor@univ-brest.fr
}

\begin{abstract}
:
In his Comment, A. Argnani argues that our interpretation of the STEP fault (named STEP-1 fault, in the Comment) is poorly constrained by the seismic data used in Gallais et al. (2013), and he particularly disagrees with our identification north of the Alfeo Seamount. A. Argnani is convinced that the tear fault is expressed by a belt of surface deformation, close to the Malta Escarpment. However, none of the seismic images published by A. Argnani show a crustal scale structure that could be associated with the presence at depth of a lithospheric tear. In that paper we documented the presence of a sub-vertical crustal scale fault, located $50 \mathrm{~km}$ east of the Malta Escarpment, with a northward increasing vertical offset (Gallais et al., 2013). The track of this fault towards the north could be extended following the position the fault "F6", mapped $20 \mathrm{~km}$ east of the Malta Escarpment by Nicolich et al. (2000). In fact these authors reported an offset of the crust associated with activity the fault "F6", suggesting the lithospheric tear at depth at the edge of the lonian slab is distinct from the Malta Escarpment.
\end{abstract}

Keywords : subduction zones ; lithospheric fault ; slab roll-back ; active deformation ; multichannel seismic profiles ; slab tear

\section{South of Alfeo Seamount: The southern tip of the STEP fault}

A. Argnani pointed out that the grid of profiles used in our study is not enough dense to constrain the position of the STEP fault at the western edge of the lonian slab. As we clearly stated in our paper, our study dealt primarily with the southern termination of the STEP fault, south of the Alfeo Seamount, 
based on newly processed seismic profiles (see position of the data used in Figure 2, Gallais et al., 2013). Accordingly, our study allowed a quantification of the vertical displacement associated with the presence of a very steeply E-dipping fault, observed on two newly depth reprocessed Archimede lines (see Figures 4 and 5, Gallais et al., 2013) and on other available seismic lines in the literature (ION-1 and CROP-M3) (Cernobori et al., 1996; Hirn et al., 1997; Polonia et al., 2011). The Archimede seismic profiles image a nearly vertical fault that cuts completely through the Calabrian accretionary wedge. Activity of this fault leads to a strong vertical offset of the entire sedimentary pile and of the crustal basement and the emplacement of a Pleistocene syntectonic basin (Hirn et al., 1997; Nicolich et al., 2000). The vertical offset decreases towards the south and the fault is no longer visible on the southernmost Archimede 02 line (Gallais et al., 2013).

A. Argani remarks that "the surface expression of a STEP is commonly ambiguous and poorly documented". However, in our main study area (south of Alfeo Seamount) there is a striking vertical displacement, which we were able to quantify using pre-stack depth migrated seismic profiles and which increases from $275 \mathrm{~m}$ (on Archimede line 16) to $645 \mathrm{~m}$ (on Archimede line 
17). This amount of vertical throw on the fault is defined on the basis of a clear offset in the base of the Messinian and corresponds to an asymmetric syn-tectonic basin with a thickness of $\sim 645 \mathrm{~m}$. We attribute this vertical down to the East movement, to the presence at depth of a lithospheric tear (STEP) that propagates towards the south. We are also able to map the southern termination of this tear, since a vertical displacement is no longer imaged south of the latitude $\mathrm{N} 36.4^{\circ}$.

\section{The Alfeo Seamount and the northern end of the STEP fault}

We described and emphasized that the proposed prolongation towards the north is based on other geophysical data (Figure 1, in the reply). The prolongation to the north of the steeply Edipping fault is based on correlation with previous seismic interpretations (Hirn et al., 1997; Nicolich et al., 2000; Argnani and Bonazzi, 2005). As already proposed in Gallais et al. (2013), two candidates could be retained from the literature for the prolongation of the fault:

- The fault "F6" that is located $20 \mathrm{~km}$ east of the Malta Escarpment, mapped by Nicolich et al. (2000),

- A set of faults that delineates a "belt of surface deformation, close the Malta Escarpment”, mapped by Argnani and Bonazzi (2005).

Undeniably, A. Argnani used a denser grid of of MESC profiles to map the structures close to the Alfeo Seamount and towards the north (Figure 1, in the comment). However, none of the faults mapped using these data has a crustal scale expression that indicates the presence of a tear at depth. Regarding the set of faults mapped by Nicolich et al. (2000), A. Argnani argued that the main fault identified by Nicolich and co-authors is the fault named "F4". But these authors clearly recognized the fault "F6" as the best expressed feature on the ETNASEIS dataset (Hirn et al., 1997; Nicolich et al., 2000): "Moreover, this region is the site of a major intracrustal perturbation, fault F6, with a very clear large throw in the Mesozoic/Paleogene 
sediments and lower crust" (in Nicolich et al., 2000). Based on the MESC profiles shown in the Argnani papers (see position Figure 1) (Argnani and Bonazzi, 2005; Argnani, 2009; Argnani et al., 2012), these authors cannot rule out the existence of a major fault "F6". Indeed, on Figure 2, the marked structure "F6?" appears to correspond exactly to the fault "F6" of Nicolich et al. (2000). The fault "F6" is our preferred interpretation for the prolongation towards the north of our quasi vertical fault. Hirn et al. (1997) and Nicolich et al. (2000) reported offset of the crustal basement associated to the fault "F6".

\section{How far apart from the escarpment?}

Following these interpretations, south of the Alfeo Seamount, the main surface expression of the lithospheric tear (STEP) at depth is clearly disconnected from the Malta Escarpment. The crustal scale fault is located roughly $50 \mathrm{~km}$ further east. Towards the north, the track of the tear follows the "F6" fault, located $20 \mathrm{~km}$ east of the Malta Escarpment. At the latitude of Syracusa, we distinguish three distinct tectonic features (in particular south of the Alfeo seamount): the Malta Escarpment, the lateral ramp of the Calabrian accretionary wedge and the STEP fault (see Figure 8, Gallais et al., 2013) each separated by about $20-30 \mathrm{~km}$. Within this framework, we want to point out that we disagree with the interpretation of Minelli and Faccenna (2010) who interpreted the lateral ramp of the Calabrian accretionary wedge to be located within the wedge itself, which is not consistent with the compressional deformation observed (in the form of tightly spaced anticlines) outboard (to the west) of this limit. So our prefered interpretation of a crustal scale fault at the western edge of the Ionian remains the track of the STEP-1 fault (Figure 1). This conclusion is by no means in contradiction with the presence of the "surface belt of deformation" mapped in the study of Argnani. However, we are still convinced that although close to the Malta Escarpment, the tear progates at depth 20 
to $50 \mathrm{~km}$ far to the east, associated with the presence of a crustal scale fault and syntectonic basins that attest to its recent activity.

\section{The Hyblean Onshore}

The prolongation of the fault onshore is beyond the scope of our original paper (Gallais et al., 2013). However, we will briefly discuss two possible prolongations onshore NE Sicily of the STEP-1 fault. We agree with A. Argnani that the popular Tindari-Lipari or Taormina lines represent "untested" features for the expression NE Sicily of tear at depth. The only information that suggests the presence of a tear at depth are the tomographic images (Wortel and Spakman, 2000; Piromallo and Morelli, 2003) and the signature of the Etna volcanism (Gvirtzman and Nur, 1999). We used some focal mechanisms to look for some strike-slip movement in the upper plate of Sicily (Pondrelli et al., 2006), that could suggest the occurrence of tearing. A. Argnani noted that one focal mechanism is not "right lateral strike slip mechanism" on the Figure 7 (Gallais et al., 2013). In fact he correctly identified a drafting error on Figure 7 selecting the focal mechanism with an E-W trending fault instead of the closer NW/SE trending one.

In any case, we have no data to favour one prolongation. We proposed a possible and feasible geometry for this prolongation of the fault observed offshore, closer to the trend of the Taormina line and which is based largely on micro-seismicity. We consider it reasonable to interpret a belt/corridor of surface deformation NE of Sicily that accommodates the rollback at depth, which could be located in between the Taormina and Tindari-Lipari lines.

Finally, we would also like to disagree with Argnani's summary of our work wherein he states "Gallais et al have traced a right-lateral strike-slip fault that extends from south of the Alfeo Seamount all the way to the Tyrrhenian Sea". No, we characterized the kinematics of the fault from south of Alfeo to approximately the position of Mount Etna as being a nearly 
vertical down to the East "normal fault" (and not a strike-slip fault). It is only on land from Mount Etna toward the Tyrrhenian Sea to the NW that we, as well as other authors have sought to identify possible dextral strike-slip faults. We agree with Argnani that identifying the single (or multiple) fault trace(s) here is challenging and requires additional work (for instance a dense GPS network possible coupled with seismic stations).

\section{Conclusions}

South of the Alfeo Seamount, our dataset clearly allows us to map the superficial expression of the STEP fault, located $50 \mathrm{~km}$ east of the Malta escarpment and thus completely disconnected from this structure. North of Alfeo seamount, we remain convinced that the preferred prolongation following the interpretation of Nicolich et al. (2000) is robust, since the largest amount of crustal displacement reported by these authors is along the major fault "F6". Between the Alfeo seamount and Mount Etna, the distance between the two structures STEP-1 fault / F6 and the Malta escarpment decreases to around $20 \mathrm{~km}$ and thus it becomes increasingly difficult to attribute deformation to one or the other structure. Our favored interpretation does not rule out the belt of surface deformation mapped by Argnani, which may be related to deep-seated deformation being widely distributed at the surface of the thick accretionary wedge. The best way to determine how and where the surface expression of this lithospheric scale vertical fault continues north of Alfeo seamount is to perform new marine geophysical studies in this sector.

\section{Figures}

Figure 1: Structural map of Argnani and Bonazzi (2005) with the position of our interpreted STEP-1 fault and its prolongation the fault "F6" of Nicolich et al. (2000). We also add the 
position of the MESC available in the literature (profile MESC 09 is shown on Figure 2 (Argnani and Bonazzi, 2005; Argnani, 2009) and MESC 08 (Argnani et al., 2012)).

Figure 2: Seismic profile MESC 09 showing some of the superficial faults identified by Argnani and Bonazzi (2005). Fault A is recognized as the principal extensional fault on this profile, but with no crustal scale signature. We add the possible location of the fault "F6". Unfortunately the eastern portion of the seismic profile is not shown. See position of this seismic line on figure 1.

References

Argnani, A., 2009. Evolution of the Tyrrhenian slab tear and active tectonics along the western edge of the Tyrrhenian subducted slab. in: van Hinsbergen, D.J. J., Edwards, M. A., Govers, R. (Eds.), Collision and Collapse at the Africa-Arabia-Eurasia subduction zone. Geological Society, Special Publication, 311, London, pp 193-212.

Argnani, A., Armigliato, A., Pagnoni, G., Zaniboni, F., Tinti, S. and Bonazzi, C., 2012. Active tectonics along the submarine slope of south-eastern Sicily and the source of the 11 January 1693 earthquake and tsunami. Nat. Hazards Earth Syst. Sci., 12: 1311-1319.

Argnani, A. and Bonazzi, C., 2005. Malta Escarpment fault zone offshore eastern Sicily: PlioQuaternary tectonic evolution based on new multi-channel seismic data. Tectonics, 24: TC4009, doi:10.1029/2004TC001656.

Cernobori, L., Hirn, A., McBride, J.H., Nicolich, R., Petronio, L., Romanelli, M. and STREAMERS/PROFILES Working Groups, 1996. Crustal image of the lonian basin and its Calabrian margins. Tectonophysics, 264: 175-189.

Gallais, F., Graindorge, D., Gutscher, M.A. and Klaeschen, D., 2013. Propagation of a lithospheric tear fault (STEP) through the western boundary of the Calabrian accretionary wedge offshore eastern Sicily (Southern Italy). Tectonophysics, v. 602, p. 141-152 doi:10.1016/j.tecto.2012.12.026.

Gvirtzman, Z. and Nur, A., 1999. The formation of Mount Etna as the consequence of slab rollback. Nature, 401: 782-785.

Hirn, A., Nicolich, R., Gallart, J., Laigle, M., Cernobori, L. and Group, E.S., 1997. Roots of Etna volcano in faults of great earthquakes. Earth and Planetary Science Letters, 148: 171-191.

Nicolich, R., Laigle, M., Hirn, A., Cernobori, L. and Gallart, J., 2000. Crustal structure of the lonian margin of Sicily: Etna volcano in the frame of regional evolution. Tectonophysics, 329: 121139.

Piromallo, C. and Morelli, A., 2003. P wave tomography of the mantle under the AlpineMediterranean area. Journal of Geophysical Research, 108(B2): 2065,doi:10.1029/2002JB001757. 
Polonia, A., Torelli, L., Mussoni, P., Gasperini, L., Artoni, A. and Klaeschen, D., 2011. The Calabrian arc subduction complex in the Ionian Sea: regional architecture, active deformation and seismic hazard. Tectonics, 30: TC5018, doi:10.1029/2010TC002821.

Pondrelli, S., Salimbeni, S., Ekström, G., Morelli, A., Gasperini, P. and Vannucci, G., 2006. The Italian CMT dataset from 1977 to the present. Physics of the Earth and Planetary Interiors, 159: 286-303.

Wortel, M.J.R. and Spakman, W., 2000. Subduction and Slab Detachment in the MediterraneanCarpathian Region. Science, 290: 1910-1917. 


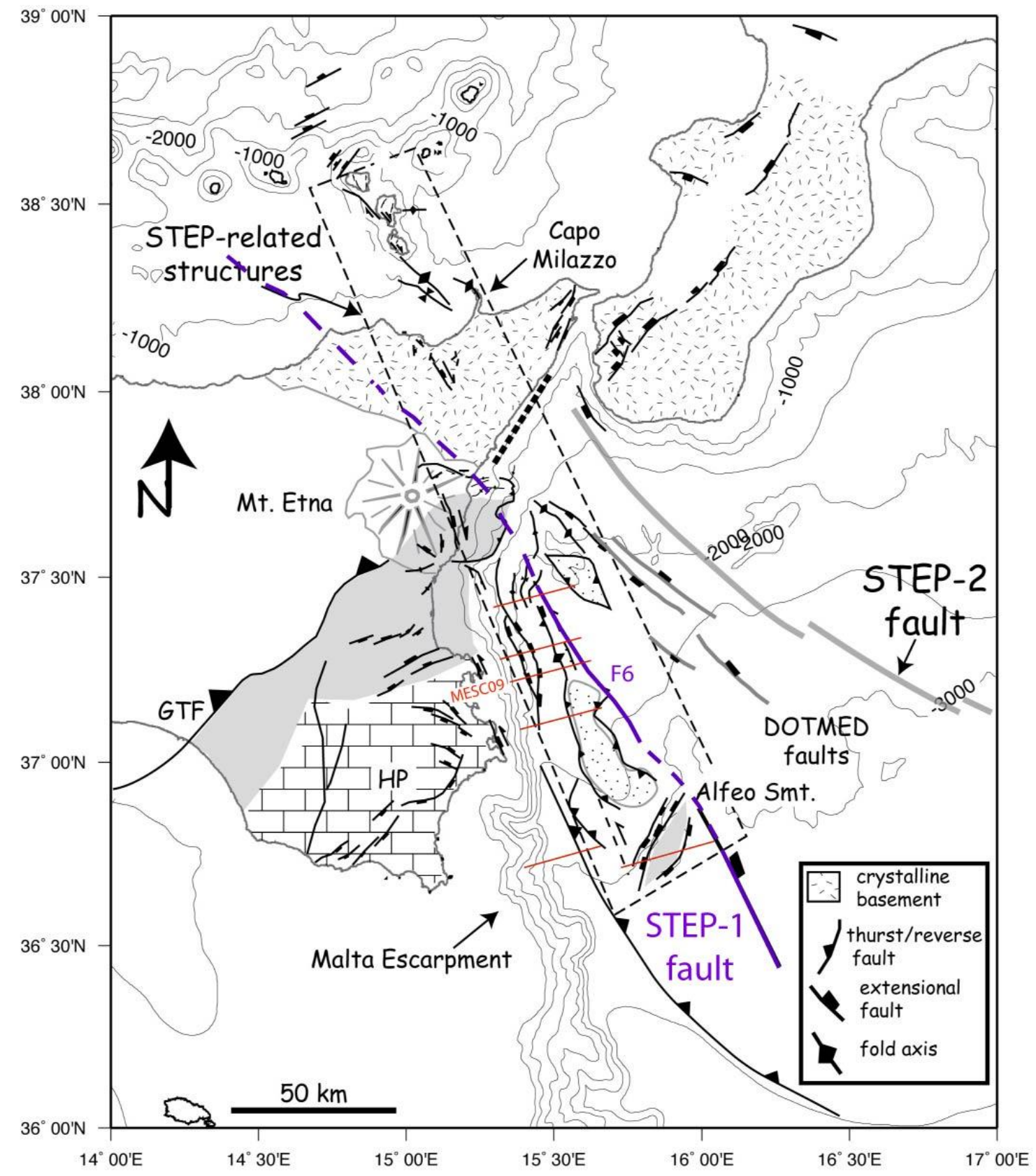

Figure 1 


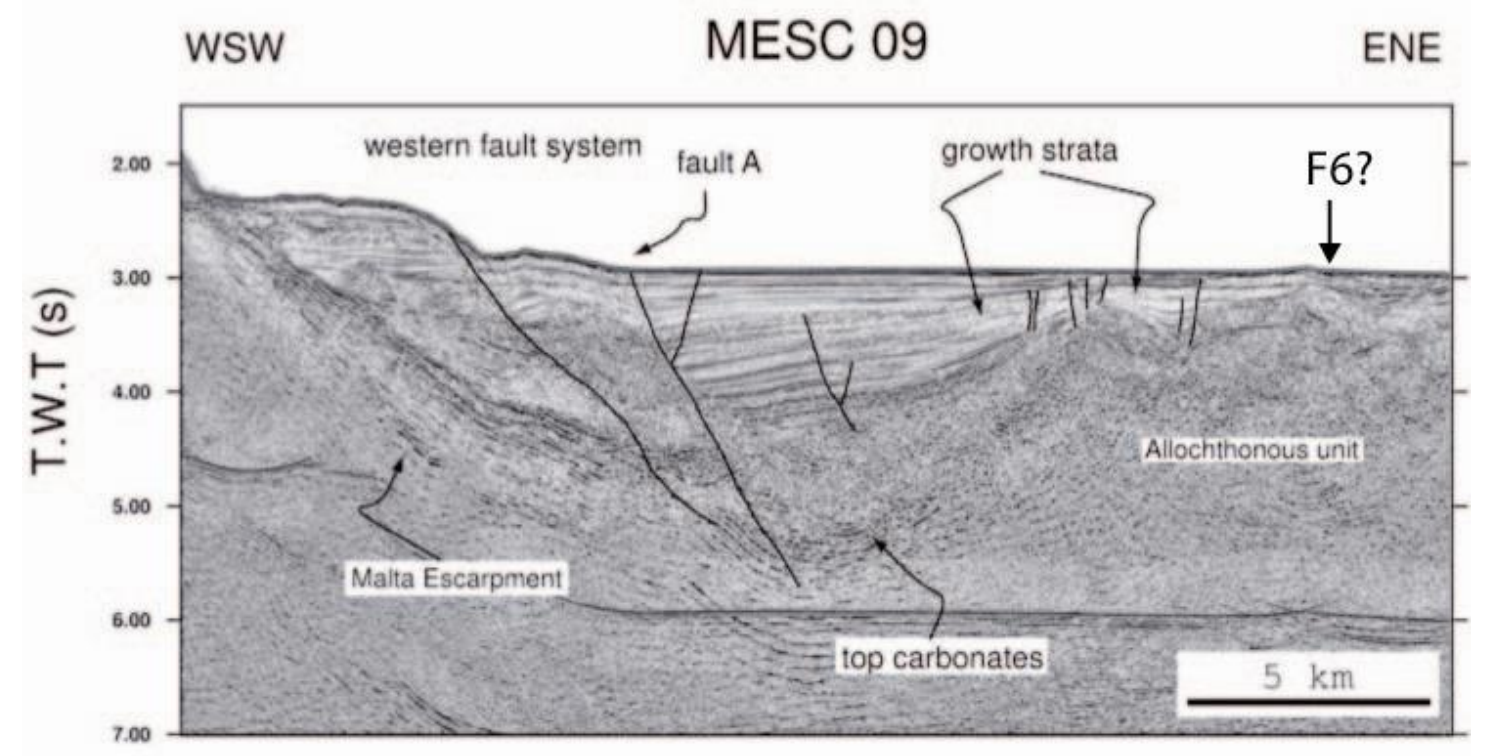

Figure 2 